\begin{tabular}{|c|c|c|}
\hline Beitr. Ent. & Bexlin & ISSN 0005-805X \\
\hline $49(1999) 2$ & S. $343-356$ & 13.09 .1999 \\
\hline
\end{tabular}

\title{
On the Staphylinidae of La Gomera (Canary Islands), with descriptions of four new species
}

\section{(Coleoptera)}

With 4 figure plates and 1 table

\section{VOLKER ASSING}

\section{Summary}

The results of a field trip to La Gomera are presented. More than 45 species of Staphylinidae were recorded, at least 31 of them either Canarian endemics or island endemics of La Gomera. Four species, all of them presumably island endemics, are described and distinguished from related taxa:Micropeplus gomerensis sp. n., Leptobium gomerense sp. n., Oligota stefaniae sp. n., and Alevonota sollemnis sp. n. Their sexual characters and further distinguishing characters are figured.

\section{Key words}

Coleoptera - Staphylinidae - Micropeplus - Leptobium - Oligota - Alevonota - Palaearctic - Canary Islands - La Gomera - taxonomy - new species - endemism

\section{Zusammenfassung}

Bei Freilanduntersuchungen auf der Insel La Gomera wurden mehr als 45 Staphylinidenarten nachgewiesen, davon mindestens 31 Kanarenendemiten oder Inselendemiten von La Gomera. Vier Arten, allesamt sehr wahrscheinlich Inselendemiten, werden beschrieben und von nahverwandten Taxa unterschieden: Micropeplus gomerensis sp. n., Leptobium gomerense sp. n., Oligota stefaniae sp. n. und Alevonota sollemnis sp. n. Die Genitalien sowie weitere Differentialmerkmaie werden abgebildet.

\section{Introduction}

According to the recent checklist by HERNÁNDEZ et al. (1994), La Gomera is inhabited by 42 species endemic to the Canarian Islands, 11 of them island endemics (10 species and one subspecies). In the meantime, however, after the revisions of Othius STEPHENS and Oxypoda MANNERHEIM (ASSING, 1997, 1998a; ZERCHE, 1996) and the description of a new species of Stenus LATREILLE (ASSING, 1998b), the number of island endemics on La Gomera has risen to 15. A further increase may result from a systematic study of some Tachyporinae, especially Sepedophilus GISTEL (SCHULKE, in prep.). In the checklist referred to above, Stenus endemus PUTHZ is not considered an island endemic, as the original description is based on old 
material collected by WOLLASTON (but discovered in the Sharp and Cameron collection) from Tenerife and Fuerteventura and on further material from La Gomera (PUTHZ, 1966). However, this easily recognized species inhabits the Laurisilva (which is absent on Fuerteventura) and has, since its description, exclusively been collected on La Gomera, where it is rather common. The evidence, therefore, suggests that the records from Tenerife and Fuerteventura are based on mislabelled specimens and that $S$. endemus is in fact an island endemic of La Gomera.

During an excursion to La Gomera in December 1998, more than 4300 specimens of more than 45 species of Staphylinidae were collected. As several of the species have only rarely been recorded - some of them were described only recently - the results are listed below. In addition, the material yielded four species new to science, which are here hypothesized to represent endemics of La Gomera and which raise the number of island endemics to at least 19 (S. endemus not included).

\section{Material and acknowledgements}

Material from the following institutions and private collections was examined:

DEI Deutsches Entonologisches Institut (L. ZERCHE)

cAss author's private collection

coro Private collection P. Oromi, La Laguna

cWun Private collection P. Wunderle, Mönchengladbach

I am indebted to the colleagues indicated above for the loan of material. In addition, I would like to express my sincere thanks to MiCHAEL SCHÜLKE, Berlin, for a critical review of the manuscript, to Ing. ANGEL FERNÁNDEZ, Parque Nacional de Garajonay, La Gomera, for issuing a collecting permit, and to Dr. PEDro Oromi, La Laguna, for his kind assistance in contacting the authorities.

\section{Measurements}

The measurements in the descriptions are indicated in $\mathbf{m m}$ and abbreviated as follows:

HW: maximal head width including eyes

$\mathrm{HL}$ head length from front margin of clypeus to neck

PW: maximal width of pronotum

PL: length of pronotum along median line

EW: maximal width of elytra (in Micropeplus at anterior margin)

EL: length of elytra from apex of scutellum to elytral hind margin

TL: total length from apex of mandibles to hind margin of tergum VIII.

\section{New records of Staphylinidae}

Leaving aside Mocyta MULSANT \& REY (subgenus of Atheta THOMSON) and Hydrosmecta THOMSON s. 1 , taxa which urgently require revisionary work and in which identification on the species level would be little more than a good guess, the material collected in December 1998 comprised 43 species and subspecies, among them six undescribed species. At least 31 of the taxa recorded are endemic to the Canary Islands, including at least 17 island endemics of $\mathrm{La}$ Gomera. The distribution of five additional species requires clarification (Tab. 1). With the exception of Sunius palmi (FRANZ), all the island endemics are brachypterous. 
Tab. 1: Staphylinidae collected on La Gomera in December 1998.

Explanations and abbreviations: Endemism: $\mathbf{g}=$ endemic to La Gomera; $\mathrm{c}$ = endemic to Canarian archipelago; ?: distribution uncertain.

Vegetation: I: mature Laurisilva (exclusively broad-leaved trees present); II: transitional associations between I and III; III: Fayal-Brezal (predominantly Myrica faya and Erica arborea); IV: exclusively or predominantly Erica arborea present; V: stands of Pintus sp.; VI: other biolopes or habitats (see focalities).

Localities and dates: 1: N Roque de Agando, El Bailadero, 1050m, northern slope, 24.XII.; 2: El Cedro, 2km NE Ermitá N.S. de Lourdes, $1000 \mathrm{~m}, 24 . X I I$,; 3: El Cedro, near Ermitá N.S. de Lourdes, $900.1000 \mathrm{~m}$, 24.XII.; 4: NE Arure, Araxha, 1000.1100m, 24.XII.; 5: NW Vallehermoso, Teselinde, northern stope, 700m, degraded Laurisilva, 25.XII. (Leptobium gomerense sp. th. and Ocypus olens (MŪlLER) collected on grassland in westen exposition); 6: ca. $5 \mathrm{~km}$ NE Avure, Zarza, 1000m, 25.XII.; 7; ca. $4 \mathrm{~km} \mathrm{NE}$ Arure, barranco, $1000 \mathrm{~m}, 25$. XII.; 8: N Arure, Mirador de Alojera, 1000m, 25.XII.; 9, 10: Garajonay, summit, 1480m, northern slope, 26.XII.; 11, 12: Garajonay, near summit, 1450m, 26.XII.; 13, 14: N Garajonay, 1400-1450m, 26.XII, 15: EI Cedro, near Ermitá N.S. de Lourdes, 1000-1050m, 27.XII.; 16: La Laguna Alta, 1300m, 28.XII; 17: S La Laguna Grande, 1200m, 28.XII; 18: NE La Laguna Grande, barranco, ca. 1250m, 28.XII.; 19: El Rejo, $800 \mathrm{~m}$, roadside, under stones, 29.XII.; $20:$ El Cedro, bank of Cedro stream, ca. $950 \mathrm{~m}, 30$.XII.; 21 : above EJ Rejo, barranco with Salix sp., $700 \mathrm{~m}, 30 . \mathrm{XII}$.

\begin{tabular}{|c|c|c|c|c|c|c|c|c|c|c|c|c|c|c|c|c|c|c|c|c|c|c|c|}
\hline locality (no.) & & & 2 & 3 & 4 & 7 & 15 & 51 & 18 & 6 & 11 & 131 & 141 & 16 & 17 & 8 & 50 & 11 & 9 & 12 & 19 & 20 & 21 \\
\hline vegetation & $\begin{array}{l}\text { ende- } \\
\text { mism }\end{array}$ & total & & & I & & & & I & & & & In & & & & IV & & $\mathrm{v}$ & & & VI & \\
\hline $\begin{array}{l}\text { Micropeplus } \\
\text { gomerensis sp. n. }\end{array}$ & g & 14 & & & & & & & & & & & & & 14 & & & & & & & & \\
\hline $\begin{array}{l}\text { Metopsia } \\
\text { gomersnsis } \\
\text { (FRANZ) }\end{array}$ & g & 63 & & & 1 & & & & 1 & & 15 & & & 1 & 28 & & & & & 17 & & & \\
\hline $\begin{array}{l}\text { Megarthrus } \\
\text { wollastoni } \\
\text { Cucc.\& LOBC }\end{array}$ & c & 2 & & & & & 1 & & & & & & & & 1 & & & & & & & & \\
\hline $\begin{array}{l}\text { Megarthrus } \\
\text { serrsla } \\
\text { WoLLASTON }\end{array}$ & e? & 585 & 71! & 96 & & & 213 & & 76 & 1 . & 31 ] & 3 & & 15 & 71 & & & & 5 & $s$ & & & \\
\hline $\begin{array}{l}\text { Sternus guttula } \\
\text { MứLLR }\end{array}$ & & 4 & 1 & & & & & & & & & & & & & & & & & & & 1 & 2 \\
\hline $\begin{array}{l}\text { Sienus aeneot. } \\
\text { aeneotinctus } \\
\text { WolL. }\end{array}$ & c & 356 & & 4 & 9 & 6 & 7 & 37 & 34 & 24 & \begin{tabular}{l|l|l}
52 & 3
\end{tabular} & 35 & 6 & 2 & 37 & 13 & 9 & 31. & 14 & 36 & & & \\
\hline $\begin{array}{l}\text { Stenus endemus } \\
\text { Putrz }\end{array}$ & d? & 107 & 17 & 25 & 6 & & 50 & & 5 & & 2 & & & & & & & & & & & & 2 \\
\hline $\begin{array}{l}\text { Sisnus } \\
\text { exspoliatus } \\
\text { Assino }\end{array}$ & $g$ & 27 & 2 & & & 1 & 24 & & & & & & & & & & & & & & & & \\
\hline $\begin{array}{l}\text { Astents's } \\
\text { megacephalus } \\
\text { gomerense IsR. }\end{array}$ & $\mathrm{g}$ & 48 & 3 & 2 & 1 & & 5 & 17 & & 6 & 8 & & & & 1 & 3 & & & & & 2 & & \\
\hline $\begin{array}{l}\text { Metion } \\
\text { stubcoriacens } \\
\text { (WOLLASTON) }\end{array}$ & c & 284 & 15 & 28 & 16 & 2 & 77 & 60 & 11 & 11 & 26 & 1 & & 4 & 26 & 3 & & & 4 & & & & \\
\hline $\begin{array}{l}\text { Sunius } \\
\text { brevipennis } \\
\text { (Woul.) }\end{array}$ & c & 109 & 9 & 9 & & & 5 & 25 & 24 & 23 & 7 & 2. & & & & 5 & & & & & & & \\
\hline $\begin{array}{l}\text { Sunizus paimi } \\
\text { (FRANZ) }\end{array}$ & 8 & 27 & & 3 & & & 1 & 3 & & & 1 & 6 & & 1 & 5 & 1 & 2 & 1 & & 2 & 1 & & \\
\hline $\begin{array}{l}\text { Leptobium } \\
\text { debilipenne } \\
\text { (WoLL.) }\end{array}$ & g & 24 & & & & & 3 & 18 & & 1 & & & & & & 2 & & & & & & & \\
\hline
\end{tabular}




\begin{tabular}{|c|c|c|c|c|c|c|c|c|c|c|c|c|c|c|c|c|c|c|c|c|c|c|c|}
\hline $\begin{array}{l}\text { Leptobitum } \\
\text { gomerense sp. } \mathbf{n}\end{array}$ & 8 & 7 & & & & & & 7 & & & & & & & & & & & & & & & \\
\hline $\begin{array}{l}\text { Othitus } \\
\text { brachypterns } \\
\text { WOLLASTON }\end{array}$ & $\mathbf{g}$ & 7 & & & & & & & & & & & & 2 & 5 & & & & & & & & \\
\hline $\begin{array}{l}\text { Othius } \\
\text { microphtalmus } \\
\text { COFFAIT }\end{array}$ & g & 5 & 3 & 2 & & & & & & & & & & & & & & & & & & & \\
\hline $\begin{array}{l}\text { Gobrius } \\
\text { canariensis } \\
\text { (FAUVE) }\end{array}$ & 0 & 171 & 27 & 22 & 18 & 14 & 19 & & 13 & 1. & 7 & 10 & 1 & & 8 & & 2 & & 6 & 7 & 2 & 5 & 9 \\
\hline $\begin{array}{l}\text { Pseudocypus } \\
\text { subaenescens } \\
\text { (WolL.) }\end{array}$ & c & 2 & & & & & & 2 & & & & & & & & & & & & & & & \\
\hline $\begin{array}{l}\text { Ocypus olens } \\
\text { (MOLLER) }\end{array}$ & & 7 & & & & & & 7 & & & & & & & & & & & & & & & \\
\hline $\begin{array}{l}\text { Allantogoerius } \\
\text { sylvaticus } \\
\text { (WorL.) }\end{array}$ & $\mathrm{g}$ & 46 & 5. & $s$ & & 1 & i) & 29 & & 4 & & & & & & & & & & & & & ] \\
\hline $\begin{array}{l}\text { Heterothops } \\
\text { canariensis } \\
\text { ISRAELSON }\end{array}$ & c & 14 & & & & & 1 & 2 & & & & 3 & & & 2 & 5 & & & & & 1 & & \\
\hline $\begin{array}{l}\text { Quedius } \\
\text { expectatus } \\
\text { IsRAELSON }\end{array}$ & $\mathbf{g}$ & 2 & & & & & & & & & & & & 2 & & & & & & & & & \\
\hline $\begin{array}{l}\text { Quedius } \\
\text { megalops } \\
\text { WoLlASTON }\end{array}$ & c & 59 & & & & & & $\mathbf{l}$ & 10 & 3 & & 1 & 3 & 6 & 12 & 13 & & 2 & 8 & & & & \\
\hline $\begin{array}{l}\text { Habrocerns } \\
\text { capillaricornis } \\
\text { (GRAV.) }\end{array}$ & & 109 & & & 103 & 6. & & & & & & & & & & & & & & & & & \\
\hline $\begin{array}{l}\text { Habrocerts } \\
\text { canariensis } \\
\text { Ass.\& WUN. }\end{array}$ & c & 67 & 20 & 22 & 4 & & 17 & & & & 3 & & & & 1 & & & & & & & & \\
\hline $\begin{array}{l}\text { Trichophya } \\
\text { piljcornis } \\
\text { (GYLLENHAL) }\end{array}$ & & 40 & 4 & 5 & 1 & $\mathrm{l}$ & 4 & & & & & & & & 24 & & & & & 1 . & & & \\
\hline $\begin{array}{l}\text { Myceloports } \\
\text { solidicomis } \\
\text { WoLt. }\end{array}$ & $?$ & 29 & 1 & & & & & 20 & & 3 & 5 & & & & & & & & & & & & \\
\hline $\begin{array}{l}\text { Ischnosoma } \\
\text { moniticorne } \\
\text { (WOLL.) }\end{array}$ & c & 35 & 5 & 4 & 1 & & 4 & 6 & 3 & 1 & & & & & 10 & $i$ & & & & & & & \\
\hline $\begin{array}{l}\text { "Bnyophactis" } \\
\text { filicornis } \\
\text { (WoL.L.) }\end{array}$ & 0 & 2 & & & & & & 1 & & & & 1 & & & & & & & & & & & \\
\hline $\begin{array}{l}\text { Lordithon } \\
\text { thoracicus (F.) }\end{array}$ & & 16 & 1 & 1 & 3 & & & & & & 1 & & & & & & & & & 3. & & & 7 \\
\hline $\begin{array}{l}\text { Sepedophilus sp. } \\
n \text { (SCHƯlKE, in } \\
\text { prep) }\end{array}$ & $?$ & 5 & & 2 & & & & 1 & & & & & & & & & & & & & & & 2 \\
\hline $\begin{array}{l}\text { Sepedophilus sp. } \\
n \text { (ScHULkE, in } \\
\text { prep) }\end{array}$ & $?$ & 193 & 19 & IS & & & 26 & 38 & 56 & & & 10 & & & 23 & 3 & 1 & & & 1 & & & 1 \\
\hline
\end{tabular}




\begin{tabular}{|c|c|c|c|c|c|c|c|c|c|c|c|c|c|c|c|c|c|c|c|c|c|c|}
\hline $\begin{array}{l}\text { Tachyponus } \\
\text { nitidulus (F.) }\end{array}$ & & 18 & & & 1 & & 1] & 8 & & & & & & & 2 & & 2 & 3 & 1 & & & \\
\hline $\begin{array}{l}\text { Oligota stefaniae } \\
\text { sp. } \mathbf{n} \text {. }\end{array}$ & $\mathbf{g}$ & 5 & & 3 & & & 2 & & & & & & & & & & & & & & & \\
\hline $\begin{array}{l}\text { Hydrosmecta s. } 1 . \\
\text { sp. }\end{array}$ & 7 & 1 & & & & & & & & & & & & & 1 & & & & & & & \\
\hline $\begin{array}{l}\text { Aloconota } \\
\text { aegeptiaca } \\
\text { (Morsch.) }\end{array}$ & & 37 & 3 & 8 & & & & & & & & & & & & & & & & & 25 & 1 \\
\hline $\begin{array}{l}\text { Alaconota } \\
\text { amnigena } \\
\text { (WoLLASTON) }\end{array}$ & c & 5 & 2 & 2 & & & & & & & & & & & & & & & & & 1 & \\
\hline $\begin{array}{l}\text { Alevonota } \\
\text { sollenmis sp. } \mathrm{n} .\end{array}$ & $g$ & 16 & & 16 & & & & & & & & & & & & & & & & & & \\
\hline $\begin{array}{l}\text { Atheta } \\
\text { aeneicollis } \\
\text { (SHARP) }\end{array}$ & & 142 & 3 & 2 & 4 & & 47 & & 2 & & 2 & 15 & & & 32 & & 8 & & 9 & 17 & & \\
\hline $\begin{array}{l}\text { Atheta laeta } \\
\text { (WOLLASTON) }\end{array}$ & $c$ & 124 & 45 & 39 & 4 & 1 & 25 & & & & & & & & 2 & & & & & & & 8 \\
\hline $\begin{array}{l}\text { Atheta (Mocyta) } \\
\text { spp. }\end{array}$ & & 1115 & 104 & 141 & 52 & 11 & 242 & 23 & 16 & 7 & 39 & 68 & 1 & 2 & 311 & 15 & 1 & 4 & 1 & 67 & 2 & 8 \\
\hline $\begin{array}{l}\text { Oxypoda } \\
\text { wunderlei } \\
\text { ZERCFE }\end{array}$ & 8 & 208 & 25 & 58 & di & 1 & 90 & & 25 & & 3 & & & & 5 & & & & & & & \\
\hline $\begin{array}{l}\text { Oxypada } \\
\text { gitlerforsi } \\
\text { ZERCHE }\end{array}$ & g & 2 & & & ] & i & & & & & & & & & & & & & & & & \\
\hline $\begin{array}{l}\text { Oxypoda } \\
\text { aranensis } \\
\text { (ISRAELSON) }\end{array}$ & $g$ & 219 & 3 & 1 & & & & & 51 , & 16 & & 19 & & & 114 & & 3 & & & 8. & & \\
\hline $\begin{array}{l}\text { Aleochara } \\
\text { funebris } \\
\text { WOLLASTON }\end{array}$ & & 1 & & & & & & & & & & & & & & & & & & & & 1 \\
\hline
\end{tabular}

Below, the records of some of the species are commented on; for details regarding the new species see their respective descriptions.

Metopsia gomerensis (FRANZ); According to a recent revision, only few records and specimens of this species have become known (ZERCHE, 1998). It is apparently widely distributed in the Parque Nacional de Garajonay, where it has been collected at a wide range of altitudes (600-1450m) (Tab. 1; ZERCHE, 1998). Higher abundances were only observed in Fayal-Brezal associations and in Pinus litter (Tab. 1).

Stenus exspoliatus AsSING: The recent description of this local endemic was based on only three specimens collected in the Bosque del Cedro near the Eirmitá N. S. de Lourdes (AssING, 1998b). Most of the new records are from the same area, but one $q$ was also taken in the west of the Parque Nacional de Garajonay, which reveals a wider distribution in the Gomeran Laurisilva. In contrast to $S$. aeneotinctus aeneotinctus WOLLASTON, which was common especially in Fayal-Brezal associations, $S$. exspoliatus seems to be confined to mature laurel woods (Tab. 1). A similar, though less pronounced preference was observed for $S$, endemus PUTHZ. 
Habrocerus canariensis ASSING \& WUNDERLE: This Canarian endemic is much more common on La Gomera than on other islands of the Canarian islands and preferably occurs in mature laurel woods rather than in Fayal-Brezal associations (see also AssING \& WUNDERLE, 1995). Two specimens collected on 24.XII, were teneral; previously, an immature specimen had been found in July (ASSING \& WUNDERLE, 1996). These observations suggest that either the species is not monovoltine or its life-cycle is not distinctly synchronized.

Atheta laeta (WOLLASTON): This species, which according to the literature also occurs on Tenerife and El Hierro (HERNÁNDEZ et al., 1994), was rather common in mature laurel woods, but only rarely found in Fayal-Brezal and other woodland associations.

Oxypoda wunderlei ZERCHE and $O$. gillerforsi ZERCHE: According to ZERCHE (1996), both recently described and very closely related species are common in the Gomeran Laurisilva. At the end of December, $O$. wunderle $i$ was indeed abundant in mature laurel wood (though less so in other associations), whereas, remarkably, only two $\sigma^{7} \sigma^{7}$ of $O$. gillerforsi were collected. A considerable proportion of the material of $O$. wunderlei and one of the two of ${ }^{2}$ of $O$. gillerforsi were teneral. Possibly, these two very closely related species, which have been observed to co-occur in the same localities (ZERCHE, 1996), are seasonally segregated.

\section{Descriptions of new species}

\section{Micropeplus gomerensis sp. $\mathbf{n}$.}

Figs l a, c,e

Holotype $\sigma^{7}$ : E. Islas Canarias; 17, La Gomera; ca. 1200m; S La Laguna Grande; FayalBrezal, Barranco, 28.XII. 1998, V. Assing (cAss).

Paratypes: $60^{\circ} 0^{\circ}, 7 \% q$, same data as holotype (DEI, cAss, cOro); $30^{\circ} \sigma^{*}, 2 \% q$ [1 9 only with head and pronotum], Isl. Can. La Gomera, La Laguna alta, Fayal-Brezal, 1300m, 30.10.90, Wunderle

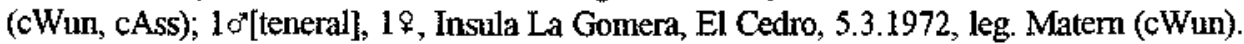

Diagnosis (terminology of morphological characters based on CAMPBELL 1968):

Measurements (mm) and ratios (range, arithmetic mean; $n=20$ ): $\mathrm{PL}: 0.38-0.44,0.41 ; \mathrm{PW}$ : $0.85-0.94,0.89$; EW: 0,74 - 0,85, 0,81; EL: $0.30-0.36,0.34$; TL: $1.9-2.6,2.2$; PW/PL: $2.07-2.28,2.19 ;$ EL/PL: $0.79-0.89,0.83 ; \mathrm{EL} / \mathrm{EW} ; 0.39-0.45,0.43$.

Both in external and sexual characters similar and closely related to $M$. stophylinoides (MARSHAM).

Body on average smaller than $M$. staphylinoides. Shape of head as in $M$. staphylinoides, anterior margin of clypeus in o' $\sigma^{\prime}$ mucronate medially; vertex with pair of elevations similar to $M$. staphylinoides; antenna bicoloured, ferrugineous, with antennomere IX \pm distinctly infuscate (in $M$. staphylinoides the whole antenna including antennomere IX is \pm reddish). Pronotum somewhat resembling that of $M$. staphylinoides, but anterior margin more deeply concave and with more pronounced anterior angles, and median cells narrower (Figs la, b). Elytra highly distinctive, very short, transverse (see ratios EL/PL and EL/EW), and fused at suture; humeral costa distinctly bent (in M. staphylinoides \pm straight), so that the lateral parts of the elytra are clearly visible in dorsal view, especially in posterior half; as in $M$. staphylinoides with two discal costae, but the areas between sutural and first and between first and second costa narrower, and with only one and two rows of large punctures, respectively (in $M$. staphylinoides with two and three rows) (Figs la, b). Hind wings completely reduced (in $M$. staphylinoides often fully developed). 

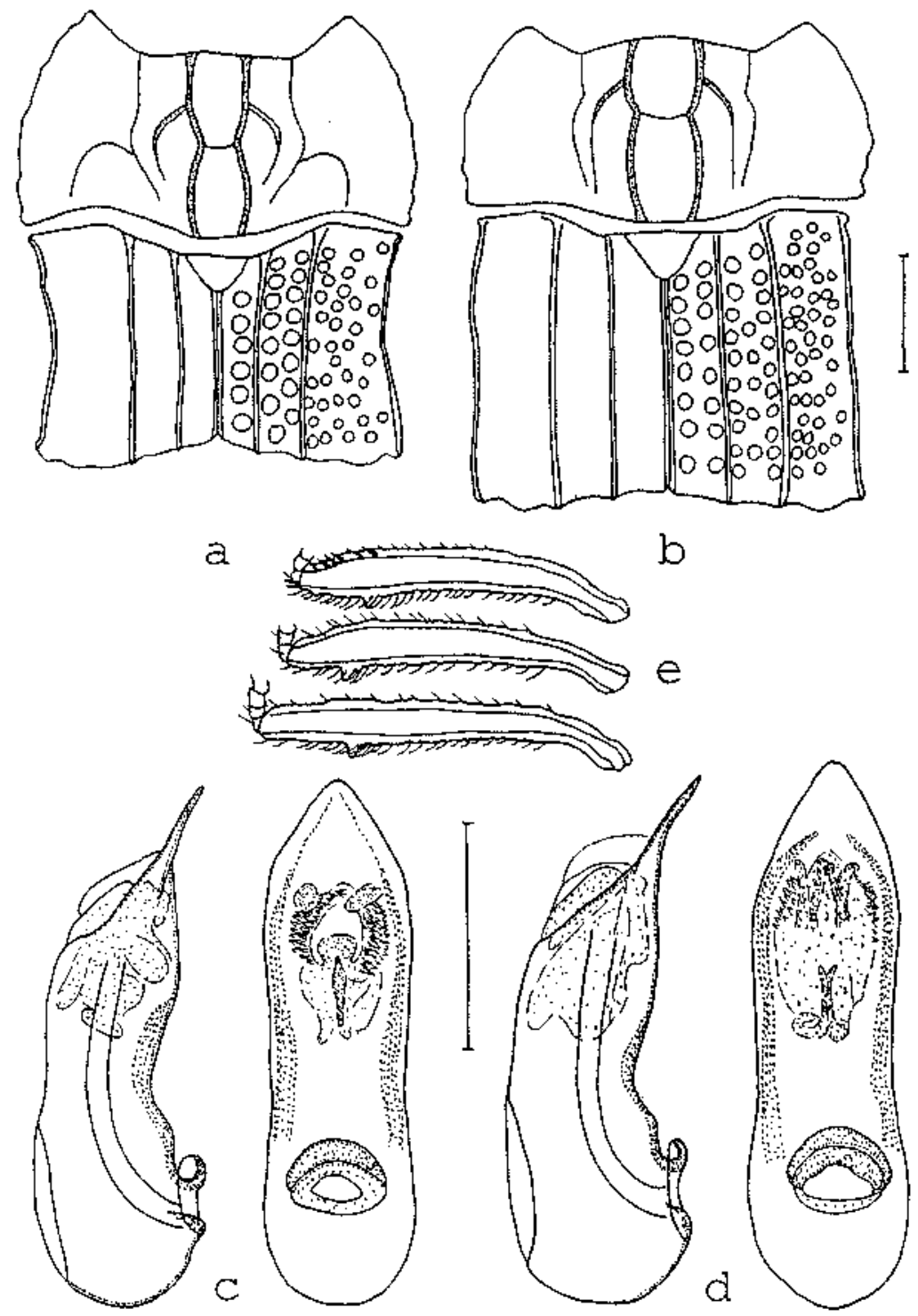

Fig. 1: Micropeplus gomerensis sp. n. (a, c, e) andM. staphylinoides (MARSHAM) (b, d): pronotum and elytra (a, b); aedeagus in lateral and ventral view (c, d); $\sigma^{*}$ pro-, meso, and metatibia (top to bottom) (e). Scales: $0.25 \mathrm{~mm}$.

Tibiae with of secondary sexual characters similar to M. staphylinoides (Fig. le). Abdomen in $\sigma^{7}$ with median carina of tergum VII in lateral view forming a right or slightly obtuse angle (in $M$. staphylinoides this angle is acute).

7: aedeagus of similar morphology as in $M$. staphylinoides, in ventral view with slightly wider and shorter apex (Figs 1c, d). 
Comparative notes: From all its Western Palaearctic congeners, this species is readily distinguished by external morphology alone, especially the short and fused elytra and the curved humeral costa.

Distribution: Previously, the genus had been recorded from the Canary Islands only once. FRANZ (1995) lists a Micropeplus scheerpeltzi NOHEL as an endemic species for El Hierro, but apparently this species has never been described. The reduced hind wings as well as the short and fused elytra suggest that $M$. gomerensis is endemic to La Gomera, where it was collected both in the Laurisilva of El Cedro and in Fayal-Brezal near La Laguna Alta and La Laguna Grande. One of collected in April was teneral.

\section{Leptobium gomerense sp. $\mathrm{n}$.}

Figs $2 \mathrm{a}, \mathrm{c}$

Holotype ơ: E. Islas Canarias; 5, La Gomera; 700m; NW Vallehermoso, Teselinde; W-slope, 25.XII.1998, V. Assing (cAss).

Paratypes: 3 $\sigma^{\circ} \sigma^{\circ}, 3$ ㅇ 7 , same data as holotype (DEI, cAss, COro); $1 \sigma^{\circ}$, Gomera, 26-XII-93, La Mérica, P. Oromi (cAss).

\section{Diagnosis}

Measurements (mm) and ratios (range; $\mathrm{n}=8$ ): $\mathrm{HL}: 0.92-1.10$; HW: $0.86-1.04 ; \mathrm{PW}: 0.83$ 0.97 ; PL: 0.97 - 1.27; EL: 0.62 - 0.76; TL: 5.7 - 6.9; HL/HW: 1.01 - 1.11; PW/HW: 0.93 0.97 ; PL/PW: 1.14 - 1.33; EL/PL: $0.60-0.69$.

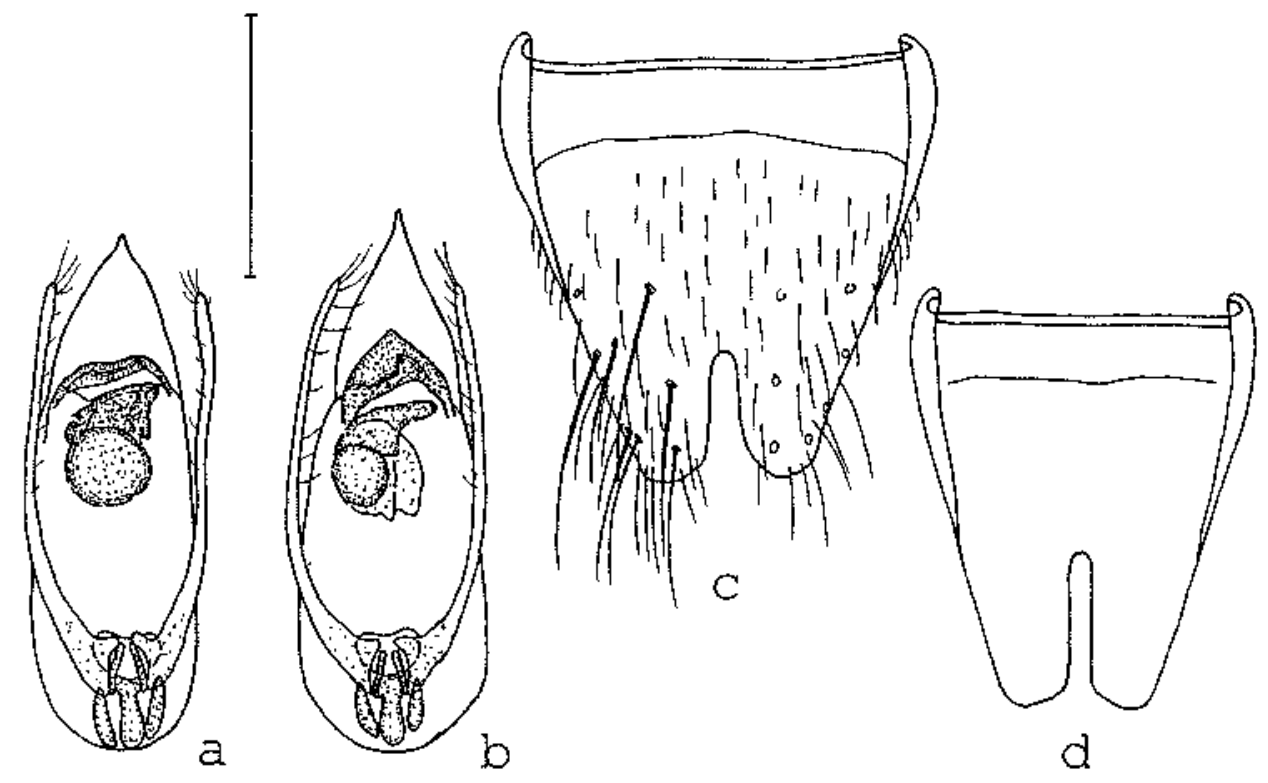

Fig. 2: Leptobium gomerense sp. $n$. (a, c) and $L$. debilipenne (WOLLASTON) (b, d): aedeagus in ventral view (a, b); \& sternum VIII (c, d); setae and pubescence omitted in d. Scale: $0.5 \mathrm{~mm}$.

Larger than its only Gomeran congener, L. debilipenne (WOLLASTON) and of different coloration: whole body uniformly reddish brown, abdomen at most only very indistinctly darkened, not bicoloured. (In L. debilipenne, the forebody is \pm yellowish brown, the appendages are testaceous, and the abdomen is clearly bicoloured, with segments III - VI dark brown to black, the apex yellowish). 
Head of similar shape as in $L$. debilipenne, also with very small eyes, which are $0.28-0.35 \mathrm{x}$ the length of postgenae in lateral view, but punctation somewhat denser; surface usually without, but occasionally ( 1 PT) with shallow microsculpture.

Pronotum as in $L$. debilipenne, but punctation on average finer and slightly denser; surface usually without, rarely (1PT) with shallow microsculpture.

Elytra as in L. debilipenne very short (see ration EL/PL); hind wings completely reduced; abdomen more densely punctured than in $L$. debilipenne. $\sigma^{*}$ : sternum VIII deeply incised, but less so than in $L$. debilipenne (Figs $2 \mathrm{c}$, d); aedeagus in relation to body size smaller, apically broader and less acute; subapical ventral sclerite of different shape (Figs 2a, b).

Comparative notes: Even without examining the types there is no doubt that $L$. debilipenne is here interpreted correctly, as WOLLASTON (1865) states that that species is "so remarkable for its clear rufo-testaceous hue (the four basal segments of the abdomen being alone black)"; for further distinguishing characters see diagnosis. From all other Canarian species of Leptobium (see HERNÁNDEZ et al. 1994; COIFFAIT, 1982), both L. gomerense and L. debilipenne differ in their respective coloration, the distinctly smaller eyes and shorter elytra, as well as in the morphology of the aedeagus.

Distribution and bionomics: Like $L$. debilipenne, L. gomerense is obviously endemic to La Gomera, not only because this conspicuous species has not yet been discovered on any other island of the Canarian archipelago, but especially because of its reduced eyes and wings, which make a wider distribution seem highly unlikely. In contrast to $L$. debilipenne, which according to WOLLASTON (1865) and my own observations occurs in woodland (Laurisilva, Fayal-Brezal), L. gomerense was collected under stones in open grassland. The locality at Teselinde was only a few hundred metres from a degraded Laurisilva (same altitude), where $L$. debilipenne was rather common.

\section{Oligota stefaniae sp. $\mathbf{n}$.}

Figs 3a, d

Holotype ơ: E. Islas Canarias; 3, La Gomera; $900-1000 \mathrm{~m}$; El Cedro; Ermitá N. S. de Lourdes; Laurisilva, 24.XII.1998, V. Assing (cAss).

Paratypes: $10^{*}, 1$, same data as holotype (cAss); 10*, 19, E. Islas Canarias; 15, La Gomera; 900 1000m; El Cedro; SW Ermitá N. S. de Lourdes; ca. 1050m, 27.XII.1998, V. Assing (cAss); 20"0, E.: Isl. Can., Gomera, Bosque del Cedro, Weg zur Ermita, $900 \mathrm{~m}, 17.7 .1995$, leg. Zerche (DEI, cAss).

\section{Diagnosis}

Measurements (mm) and ratios (range; $\mathrm{n}=5$ ): HW: $0.19-0.23$; PW: 0.24 - 0.31; PL: 0.17 - 0.21 ; EL: $0.15-0.18$; TL: $1.2-1.5$; PW/HW: $1.21-1.37$; PW/PL: $1.39-1.48$; EL/PL: $0.86-0.96$.

Externally indistinguishable from and apparently the sister species of $O$. pseudohirtus WILLIAMS (for a description of external morphology see WILLIAMS 1972).

o: sternum VIII with more convex hind margin and less transverse than in $O$. pseudohirtus (Figs 3d, e), aedeagus of similar morphology, but ventral process of median lobe less evenly arched (lateral view), apically narrower and less acute (ventral view), ventral crista smaller, internal structures of slightly different shape (Figs $3 \mathrm{a}, \mathrm{b}$ ). In $O$. hirtus WILLIAMS, the median lobe is larger, the ventral process is much longer and more straight (lateral view), and the internal stnuctures are of different shape (Fig. 3c). 

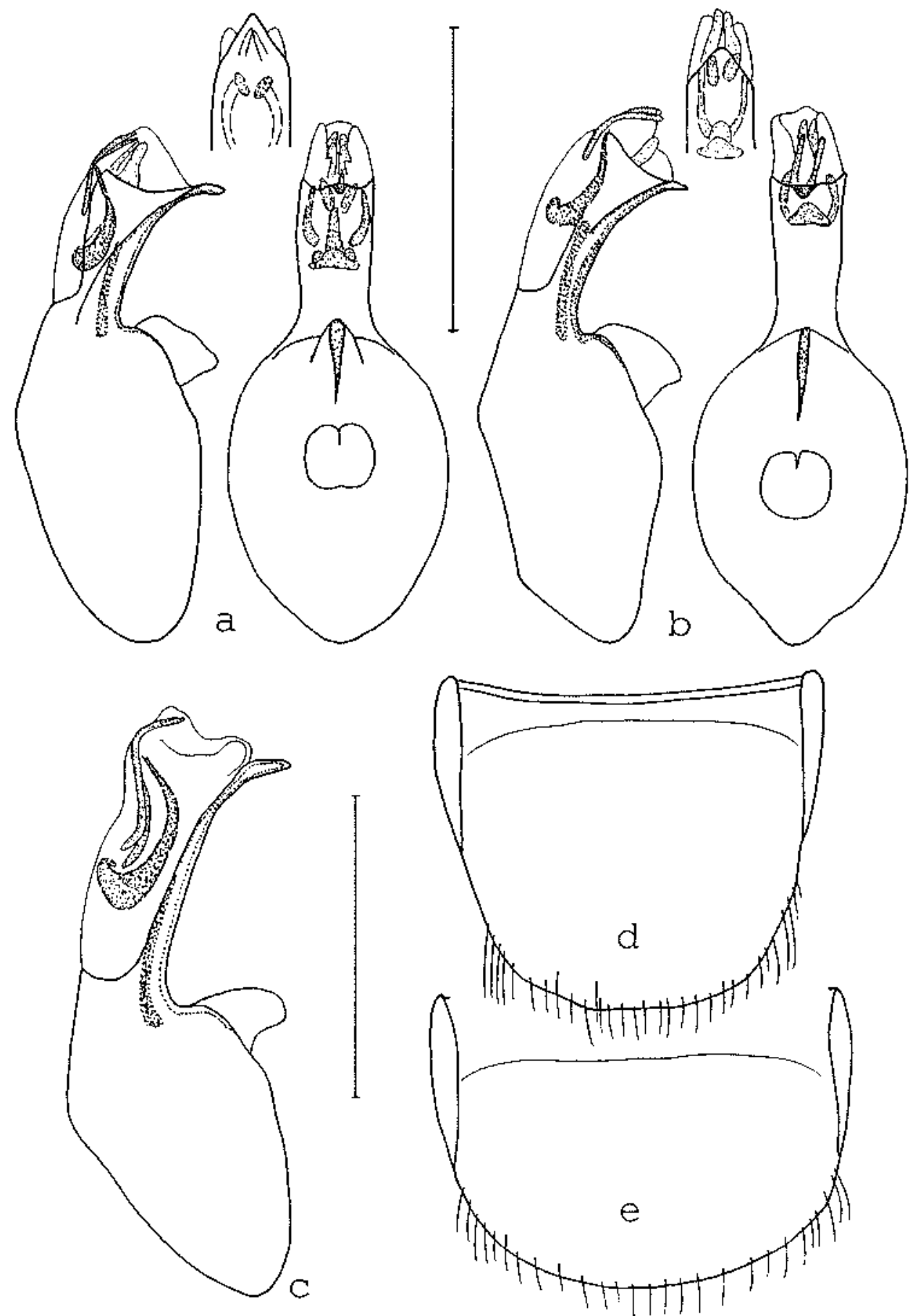

Fig, 3: Oligota stefaniae sp. n. (a, d), $O$. pseudohirtus WhluaMs (b, e), and $O$. hirtus WILlLaMs (c); median lobe of aedeagus in lateral and in ventral view, apex of ventral process in antero-ventral view $(a, b)$; aedeagus in fateral view (c); outline of or sternum VIII (d, e). Scales: $0.2 \mathrm{~mm}$. 
q: as in $O$. pseudohirtus and $O$. hirtus without sclerotized spermatheca; sternum VIII of similar shape and pubescence as in $0^{\prime}$.

Derivatio nominis: I dedicate this species to Stefanie Busch, who contributed to the discovery of this and other new species described here by spending a considerable stretch of time, even Christmas Eve, in the cloudy Laurisilva rather than on a sunny beach and by coping with an apartment that in the course of certain entomological activities was both somewhat rearranged and populated by numerous non-staphylinid arthropods.

Comparative notes: The similarities both in external and sexual characters, especially the morphology and internal structures of the aedeagus, suggest that $O$. stefaniae, $O$. hirtus WILLIAMS and $O$. pseudohirtus WLLIAMS form a monophylum, with $O$. stefaniae $+O$. pseudohirtus representing the sister group of $O$. hirtus. From all other Canarian congeners, these three species are readily distinguished especially by the small and slender body, the short elytra, the reduced hind wings, the \pm uniformly yellowish to light reddish body colour, and by their sexual characters. For distinction of $O$. stefaniae from $O$. hirtus and $O$. pseudohirtus see diagnosis. According to the key in WILliams (1972), $O$. hirtus and $O$. pseudohirtus differ in body width; however, there was considerable intraspecific variation and interspecific overlap in size-related parameters in the material available to me, so that I have been unable to appreciate this distinguishing character.

Distribution: The reductions of elytra, hind wings and pigmentation suggest that, like $O$. hirtus (La Palma) and $O$. pseudohirtus (Tenerife), $O$. stefaniae is an island endemic. Its distribution appears to be confined to La Gomera, where it was collected in the Laurisilva of El Cedro, together with the new microphthalmous species of Aleocharinae described below and the anophthalmous carabid Lymnastis gaudini gomerae FRANZ.

\section{Alevonota sollemnis sp. n.}

Figs $4 \mathrm{a}-1$

Holotype ơ: E. Islas Canarias; 3, La Gomera; $900-1000 \mathrm{~m}$; El Cedro; Ermitá N. S. de Lourdes; Laurisilva, 24.XII.1998, V. Assing (cAss).

Paratypes: $60^{\circ} \sigma^{\circ}, 9 \% 9$, same data as holotype (cAss); $10^{\circ}, 2 \% \circ$, E: La Gomera Isl. c.: El Cedro,

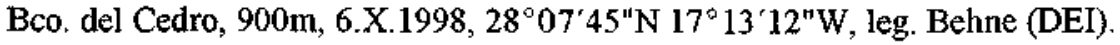

\section{Diagnosis}

Measurements (mm) and ratios (range, arithmetic mean; $n=18$ ): $\mathrm{HW}: 0.33-0.41,0.37$; $\mathrm{PW}$ : $0.39-0.48,0.44$; PL: $0.39-0.48,0.44$; EL: $0.26-0.33,0.30 ;$ TL: $2.8-3.8,3.2$; PW/HW: $1.12-1.24,1.18$; PW/PL: $0.96-1.04,1.00 ;$ EL/PL: $0.63-0.73,0.68$.

Colour of body uniformly reddish brown with the legs, the basal and the apical antennomeres slightly lighter.

Head of ovoid shape; surface with distinct \pm isodiametric microsculpture and with fine punctation; eyes very small, composed of ca. 20 ommatidia, and with pigmentation; antennae short and stout, antennomeres IV - X distinctly transverse and increasing in width (Fig. $4 \mathrm{~g}$ ); mouthparts (Figs 4d - $\mathrm{f}, \mathrm{h}$ ) as in A. rufotestacea (KRAATZ).

Pronotum slightly wider than head with maximal width near anterior angles; surface almost mat due to distinct microreticulation, punctation fine, rather dense, and barely visible; median line with shallow and narrow longitudinal impression, which is obsolete in the anterior $1 / 4$ to $1 / 3$ of pronotum; pubescence on either side of median line rather dense, depressed, and directed transversely laterad. 
Elytra short (see ratio EL/PL), fused at suture; punctation fine and rather dense; pubescence between suture and sides rather dense, depressed, and almost transverse; hind wings completely reduced.
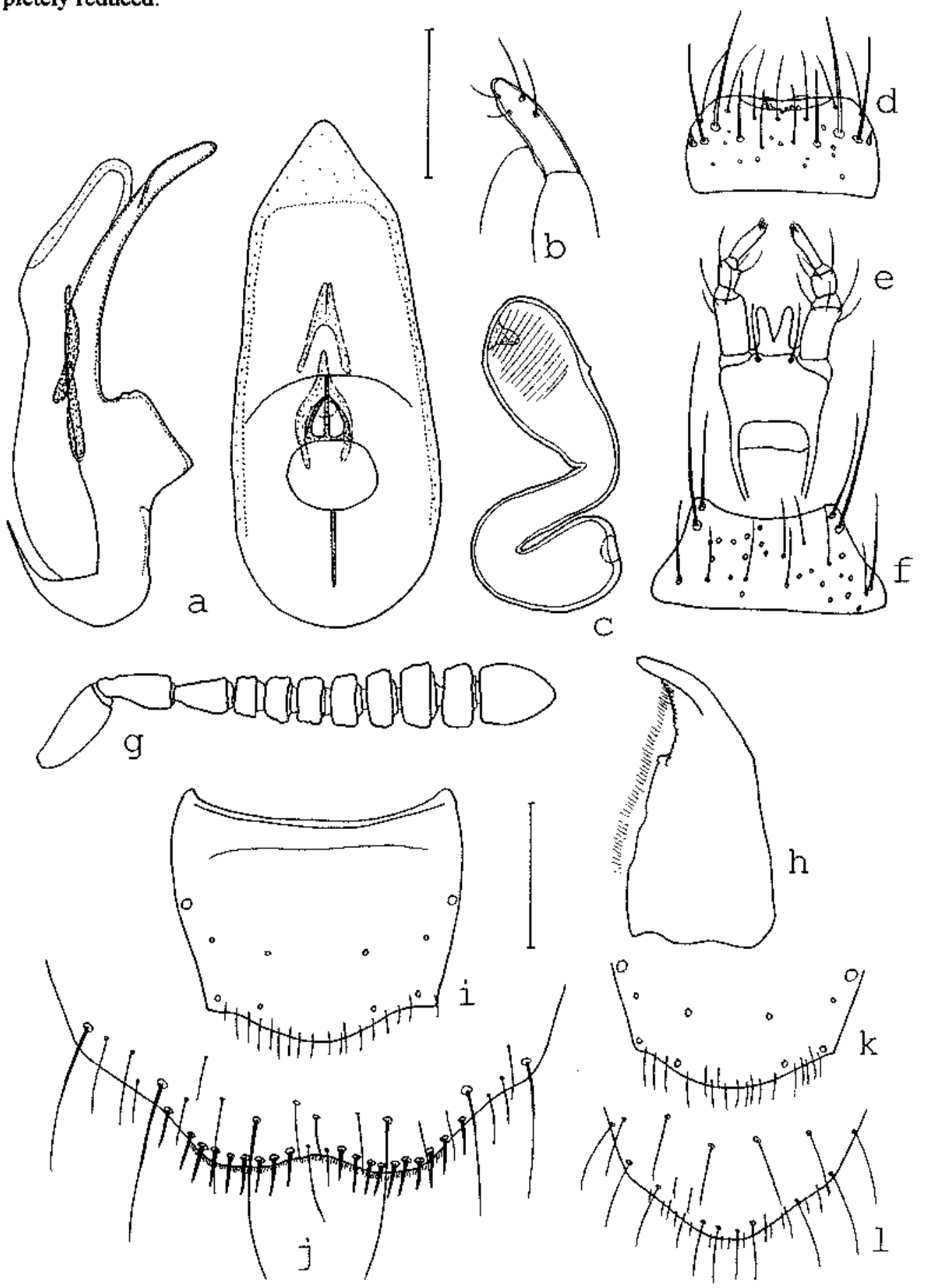


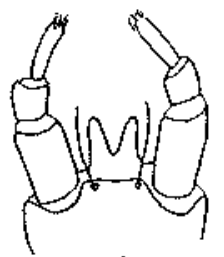

m

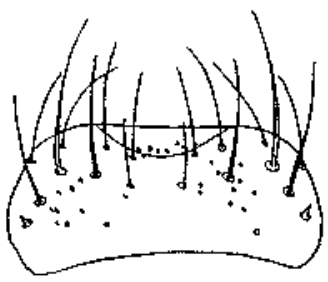

$\mathrm{n}$
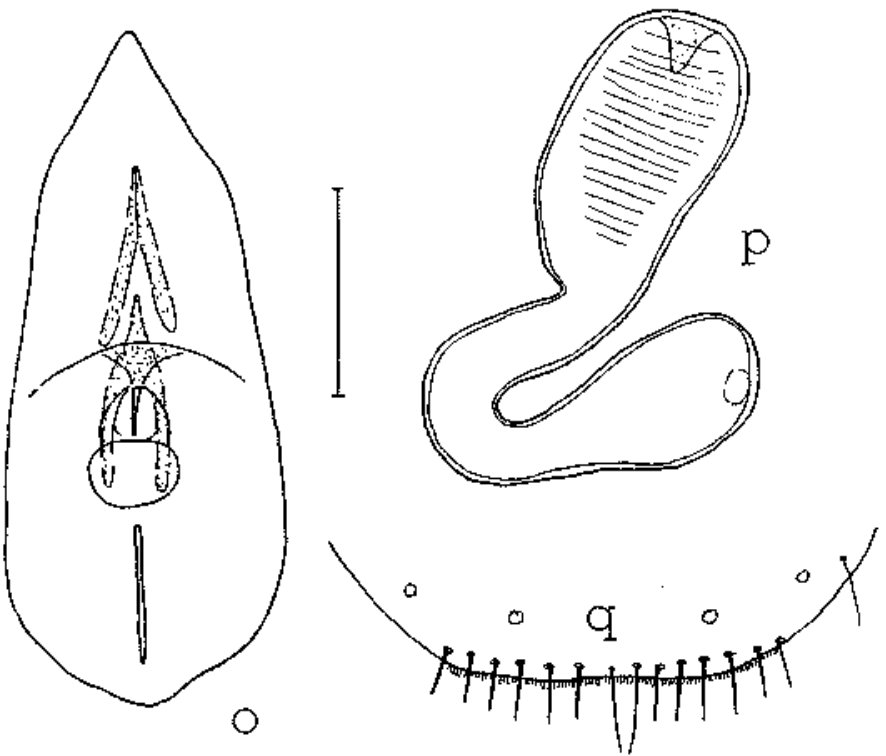

Fig. 4: Alevonota sollemnis sp. n. (a - l) and A. mfotestacea (KRAATZ) (m - q): median lobe of aedeagus in lateral (a) and in ventral view (a, o); apical lobe of paramere (b); spermatheca $(\mathbf{c}, \mathbf{p}$ ); labrum (d, n); labium (e, m); mentum (f); antenna (g); right mandible (h); $q$ tergum VIII (i); hind margin of $q$ sternum VIII $\left(\mathbf{j}\right.$, q); hind margin of o' tergum VIII $(\mathbf{k})$; hind margin of $\sigma^{2}$ sternum VII (l). Scales: a-f, h, j, m-q: $0.1 \mathrm{~mm} ; \mathrm{g}, \mathrm{i}, \mathrm{k}, \mathrm{l}: 0.2 \mathrm{~mm}$.

Legs of similar relative length as in $A$. rufotestacea.

Abdomen long and of subparallel shape, only indistinctly widened posteriorly; terga III - V with moderately deep transverse impressions; punctation fine and rather dense.

$\sigma^{\text {* }}$ tergum VIII with convex hind margin, pubescence posteriorly rather long, thin and not very dense (Fig. 4k); sternum VIII posteriorly obtusely pointed, pubescence near hind margin thin and of variable length (Fig. 41); aedeagus with shape and internal structures of median lobe and with morphology and chaetotaxy of apical lobes of parameres highly similar to $A$. rufotestacea (Figs 4a, b).

o: tergum VIII similar to $\sigma^{\prime}$ (Fig. 4i); sternum VIII posteriorly with median concavity, hind margin with row of short and stout modified setae and with micropubescence (Fig. 4j); spermatheca (Fig. 4c) of similar morphology as in A. rufotestacea.

Derivatio nominis: This remarkable species was discovered on Christmas Eve.

Comparative notes and systematics: The new species without doubt belongs to Alevonota THOMSON. With the type species of that genus, A. rufotestacea (KRAATZ), it shares the following characters: the shape and size of the body, the morphology of the antenna, ligula, maxillary and labial palpi (Figs $4 \mathrm{e}, \mathrm{m}$ ), the shape and chaetotaxy of the labrum (Figs 4d, n), the microsculpture of the forebody, the general pubescence pattern of pronotum and elytra, the longitudinal impression along the pronotal midline, the shape of the abdomen, the chaetotaxy of the $?$ sternum VIII (Figs $4 \mathrm{j}, \mathrm{q})$ and of the apical lobe of the paramere, the shape and the internal structures of the median lobe (Figs 4a, o), and the general morphology of the spermatheca (Figs 4c, p). A. sollemnis differs from $A$. rufotestacea especially in the coloration, the much smaller eyes, the more oblong head, the more distinct pronotal microsculpture, the denser and more transverse pubescence of the pronotum, 
the shorter and fused elytra, the absence of hind wings, the more distinctly concave hind margin and the stouter and shorter modified setae of the $\&$ sternum VIIL, and the slightly different shape and smaller size of the spermatheca. From other microphthalmous and anophthalmous Aleocharinae occurring in the Canary Islands, which are currently attributed to Apteranopsis JEANNEL and other genera, A. sollemnis is readily distinguished particularly by the less reduced, pigmented eyes, which are composed of $c$. 20 ommatidia and by the fused elytra. A preliminary examination of some of these species revealed that it is quite possible that they, too, may belong to Alevonota, but this question will have to be dealt with on a broader scale (ASSING \& WUNDERLE, in prep.).

Distribution: The reduction of the eyes, the short and fused elytra, and the absence of hind wings suggest that $A$. sollemnis is endemic to La Gomera, where it was sifted from Laurus Jitter in the Laurisilva of El Cedro.

\section{References}

Assing, V. 1997: The species of Othius STEPHENS, 1832 [recte: 1829] of the Canary Islands (Coleoptera, Staphylinidae, Xantholininae), - Vieraea 25 (1996): 103-115.

AssING, V. 1998a: A revision of Othius STEPHENS of the Atlantic Islands. III: Further records, new species, phylogenetics, and colonization (Insecta, Coleoptera, Staphylinidae: Xantholininae). - Reichenbachia 32: 213-224.

AssiNG, V. 1998b: Zur Kenntnis der Staphylinidenfauna der Atlantischen Inseln: neue Arten, Synonyme und Fundaten (Col., Staphylinidae) - Entomol. Nachr. Ber. 42: 139-146.

ASSING, V.\& WUNDERLE, P. 1995: A revision of the species of the subfamily Habrocerinae (Coleoptera: Staphylinidae) of the world. - Rev. Suisse Zool. 102: 307-359.

ASSING, V. \& WUNDERLE, P. 1996: A revision of the species of the subfamily Habrocerinae of the world. Supplement I. (Coleoptera: Staphylinidae). - Beitr. Ent. Berlin 46: 373-378.

CAMPselL, J. M. 1968: A revision of the New World Micropeplinae (Coleoptera: Staphylinidae) with a rearrangement of the world species. - The Canadian Entomologist 100: 225-267.

CoIfFarr, H. 1982: Coléoptères Staphylinidae de la région paléartique occidentale. IV. Sous famille Paederinae. Tribu Paederini 1 (Paederi, Lathrobii). - Nouvelle Revue d'Entomologie, Supplément, $12(4): 1-440$.

FraNZ, H. 1995: Die Ergebnisse meiner langjąhrigen Aufsammlungen der Coleopteenfauma [sic] auf der Insel Hierro (Kanarische Inseln). - Sitzungsber. Abt. I 202: 71-138.

HERNÁNDEZ, J. J; OUTERELO, R. \& GAMARRA, P. 1994: A preliminary list of Canarian Staphylinidae (Coleoptera). - Vieraea 23: 183-202.

PurHz, V. 1966: Die Stenus-Arten Madeiras und der Kanarischen Inseln (Coleoptera Staphylinidae). 21. Beitrag zur Kenntnis der Steninen. - Entomol. Blätter 62: 129-149.

Williams, S. A. 1972: The genus Oligota MANNERHEm (Col. Staphylinidae) in the Canary Islands. Entomologist's Mon. Mag. 108: 222-229.

ZERCHE, L. 1996: Die Oxypoda-Arten der Kanarischen Inseln: Taxonomie, Bionomie, Phylogenie und Biogeographie. - Beitr. Ent. Berlin 46: 277-372.

ZERCHE, L. 1998: Phylogenetisch-systematische Revision der westpaläarktischen Gattung Metopsia WOLlaSTON, 1854. - Beitr. Ent. Berlin 48: 3-101.

Author's address:

VOLKER ASSING

Gabelsbergerstraße 2

D. 30163 Hannover, Germany

e-mail: vassing.hann@t-online.de 